\title{
Model Sistem Dinamik Spasial Untuk Mengurangi Tingkat Kepadatan Ruas Jalan Utama Kota Surabaya Dengan Metode Smart Mobility
}

\author{
Mochammad Althof Ibtisaam Shiddekh dan Erma Suryani \\ Departemen Sistem Informasi, Fakultas Teknologi Informasi dan Komunikaasi, Institut Teknologi \\ Sepuluh Nopember (ITS) \\ e-mail:erma@its.sby.edu
}

\begin{abstract}
Abstrak-Kota besar, sebuah pusat atau sentral dari suatu provinsi atau daerah yang memiliki banyak aktivitas ekonomi dan gaya hidup urban yang banyak didambakan oleh banyak orang terutama yang tinggal di daerah terpencil, mereka menilai apabila dapat mengandu nasib dengan baik di pusat kota, maka hidup mereka dapat berubah kearah yang lebih baik dari sebelumnya. Dengan alasan itulah faktor urbanisasi sangat umum di kota besar. Terutama di Kota Surabaya, yang notabenenya adalah kota terbesar kedua di bumi indonesia. Dengan pergerakan urbanisasi yang masif, dan juga diikuti dengan banyaknya tenaga kerja yang tinggal di daerah lain untuk berkarir di Surabaya, terjadi lonjakn manusia yang sangat pesat terutama pada hari kerja. Banyakanya kendaraan yang menuju kearah pusat kota dan memenuhi jalan penghubung utama. Kebutuhan akan kendaraan menjadi sangat krusial. Selain kebutuhan kendaraan yang besar, kebiasaan masyarakat yang lebih menyukai penggunaan kendaraan pribadi dibandingkan dengan kendaraan umum yang telah disediakan oleh pemerintah. Mereka menilai bahwa transportasi umum kurang memadai untuk terus dapat digunakan. Maka dari itu, perlu adanya sistem yang dapat menunjang untuk menggerakan masyarakat dalam mengurangi penumpukan kendaraan dan tetap menjaga lingkungan tetap tidak dipenuhi polusi. Sistem ini akan mengaplikasikan teori Smart Mobility, salah satu aspek dari Smart City. Penelitian ini bertujuan mengurangi tingkat kemacetan yang ada sering kali terjadi pada ruas jalan utama penyambung kota Surabaya dengan kota lainnya, yaitu Ruas Jalan A. Yani, Wonokromo dan Raya Rungkut. Dengan mengaplikasikan simulasi dinamik dengan Vensim untuk melihat efek yang dapat disebabkan oleh implementasi dari Smart Mobility di Surabaya. Dari pembuatan diagram kausatik sampai dengan skenario yang akan dibuat menyesuaikan dengan potensi-potensi kota Surabaya yang akan mengedepankan implementasi menuju Smart City dan masyarakat yang lebih memiliki wawasan luas tentang teknologi kota yang bermanfaat.
\end{abstract}

Kata Kunci-Sistem Dinamik, Integrated Transportation System, Vensim, Smart City, Smart Mobility, Traffic Congestion.

\section{PENDAHULUAN}

$\mathrm{E}_{\mathrm{t}}^{\mathrm{R}}$ RA milenial yang sedang berjalan ini, moda transportasi tetap menjadi salah satu kebutuhan yang belum dapat tergantikan. Kebuthan akan berpindah tempat untuk melakukan aktivitas keseharian, jenjang karir maupun untuk rekreasi tetap membutuhkan transportasibaik umum maupun pribadi. Tetapi sudah menjadi hal yang wajar bagi mas yarakat Indonesia memilih menggunakan kendaraan pribadi karena di nilai lebih aman dan nyaman ketimabang dengan transportasi umum yang bagi sebagian masyarakat belum memadai dan terbatas dalam hal trayek. Jadi tetap saja penggunaan kendaraan masih sangat tinggi.

Efek yang sangat berdampak kepada penggunaan kendaraan pribadi yang mas if sudah pastiadalah kemacetan. Selain karena pertumbuhan jalan yang sangat kurang dari pertumbuhan kendaraan baik roda dua maupun roda empat. Rerata pengguna jalan juga akan mengambil jalan utama yang dinilai lebih mudah di pahami karena adanya marka jalan yang memadai dan mudah ditemui. Pemanfaatam jalan alternative belum dimaksimalkan oleh pengguna jalan, padahal dengan pemanfaatan jalan alternatif dapat mengurangi terjadinya pemadatan jalan. Maka dari itu, dengan bantuan sistem navigasi kota yang dapat memberikan kemudahan dalam penginformasian jalan alternatif untuk mencapai waktu perjalanan tercepat ataupun menghindari kemacetan akan sangat membantu masyrakat untuksampa ke tempat tujuan dengan aman.

Pemanfaatan jalan alternatif ini atau dapat di sebut juga ECO-Routing, selain dapat membantu dalam memberikan jalan tercepat dan menghindari adanya pemenuhan jalan, juga dapat mengurangi tingkat emisi pada lansekap kota dan juga menghemat bahan bakar bagi setiap pengguna kendaraan yang telah memakai sistem navigasi pintar yang telah terintegrasi pada kendaraan ataupun yang berada telepon pintar. Beberapa aspek seperti penggunaan peta digital yang terhubung dengan basis data dinamik, prediksi routing serta antar muka yang dapat menampilkan hasil kepada penggua yang akan langsung dapat memudahkan mereka dalam mencapai tujuan[1]. Dengan adanya navigasi yang dapat di akses dengan mudah fitur seperti prediksi biaya dan waktu tempuh dari tiap perjalanan juga dapat membantu pengendara dalam mengambil keputusan terkait dengan kehendak pengendara, apakah akan mengambil jalan tercepat ataupun yang lebih memutar apabila ingin mencapai 2 tujuan yang berbeda, sesuai dengan kebutuhan dari pengendara[2].

Pada penelitian akan membangkan rancangan model seperti yang dijelaskan sebelumnya yang dapat menjadi penerapan di Kota Surabaya di kemudian hari. Tools yang digunakan adalah Vensim yaitu adalah perangkat lunak yang dapat digunakan untuk pengembangan, analisa dan pembuatan optimasi suatu model yang berkelanjutan[3]. Untuk visualisasi aplikasi akan digunakan perangkat android yang memang banyak digunakan oleh masyarakat saat ini dengan terintegrasi aplikasi peta dari Google Inc. Dengan begitu, diharapkan dengan adanya penelitian ini, diharapkan penerapan kedepan menuju Smart City of Surabaya dapat 
terealisasi dengan cepat dan terarah serta dapat menyatukan ide-ide pintar untuk pengembangan kota yang lebih baik.

\section{TINJAUAN PUSTAKA}

\section{A. Smart City}

Konsep "kota cerdas" adalah implementasi dari pengembangan teknologi yang intensif dan berkelanjutan untuk menciptakan lingkungan yang sinergis baik untuk masyarakat, informasi, lingkungan dan elemen lain yang berhubungan[4]. Konsep Smart City juga memiliki definisi yang berkaitan dengan Smart Industry terutama pada aspek ekonomi dan jenjang perindustrian. Tak hanya menggunakan teknologi sebgai jembatan dalam membantu proses bisnis, juga untuk membantu dalam hal edukasi maupun pemerintahan serta transportasi. Kebijakan dari pemerintah kota pun dapat di monitor dan didiskusikan untuk adanya kesinambungan antar pemerintah dan masyarakat[5]. Suatu kota juga dapat di sebut "smart" apabila adanya pengimplementasian teknologi secara progresif untuk masyarakat dan komponen lain telah terintegrasu dan sinergis. Manajemen Smart City oleh pemerintah haruslah konsisten dan membagi skala prioritas sesuai dengan kebutuhan kota berdas arkan 6 dimensi[6].

Berikut ini adalah 6 dimensi yang diperlukan dalam pengimplementasian Smart City[7] :

- Smart Economy (Competitiveness)

- Smart People (Social and Human Capital)

- Smart Governance (Participation)

- Smart Mobility (Transportation and ICT)

- Smart Environment (Natural Resources)

- Smart Living (Quality of Life)

\section{B. Smart Mobility}

Konsep ini adalah salah satu 6 dimensi yang diperlukan untuk mencapai kota yang bisa dikategorikan sebagai Smart City. Konsep ini juga menjadi hal yang cukup krusial dalam implementasi Smart City, karena menuai aspek kualitas hidup masyarakat yang membutuhkan moda transportasi yang aman, cepat dan ramah lingkungan.

Berikut ini adalah tujuan utama dari Smart Mobility dalam mendukung implementasi Smart City secara utuh[8] :

- Mengurangi polusi

- Mengurangi pemadatan jalan

- Meningkatkan keselamatan masyarakat

- Mengurangi polusi udara

- Meningkatkan kecepatan transport

- Mengurangi biaya transport

\section{Traffic Congestion(Kemacetan)}

Merupakan masalah yang sering ditemui pada kota-kota besar ataupun arus jalan yang tengah padat dengan kendaraan. Dengan volume kendaraan yang melebihi kapasitas yang dapat ditampung oleh jalan. Sisi positif yang dapat diterima pada keadaan saat seperti itu memang terhindarnya tabrakan dalam kecepatan tinggi, dikarenakan pengendara lebih berhati-hati dengan jalan dan kendaraan lain disekitarnya[9]. Namun efek negatif dari terjadinya kemacetan juga cukup signifikan, yaitu seperti :

- Berkurangnya produktivitas ekonomi karena terhambatnya pengiriman barang oleh kendaraan bisnis.
- Keterlambatan pekera dalama memulai bisnis di perkantoran maupun pabrik.

- Memicu adanya konflik di jalan antar pengendara yang tidak sabar dikarenakan stress terhadap kemacetan[10].

- Polusi yang semakin besar dikarenakan penumpukan kendaraan dengan motor bakar disuatu area[11].

Kemacetan terjadi dikarenakana adanya faktor intenal dan eksternal. Dikarenakan kedua faktor tersebut, kemacetan jadi sulit dihindarkan. Salah satu faktor internal yang menyebabkan kemacetan adalah kenaikan populasikota yang semakin pesat dan meluas, penggunaan kendaraan pribadi yang lebih dominan, ataupun kendaraan umum yang belum memadai[12]. Sedangkan untuk faktor eksternal, seperti adanya pembatasan jalan jika terjadi kecelakaan, adanya suatu kegiatan yang mengambil lahan jalan, ataupun adanya perbaikan jalan atau pembangunan jalan tersebut.

\section{Model Sistem Dinamik}

Simulasi sistem dinamik merupakan simulasi kontinu yang dikembangkan oleh Jay Forrester (MIT) tahun 1960-an, berfokus pada struktur dan perilaku sistem yg terdiri dari interaksi antar variabel dan loop feedback. Hubungan dan interaksi antar variabel dinyatakan dalam diagram kausatik..

Tahapan dari proses pemodelan sistem dinamik adalah sebagaiberikut[13] :

- Problem Identification and Definition

- System Conceptualization

- Model Formulation

- Simulation and Validation

- Policy Analysis and Improvement

- Policy Implementation

\section{E. Causal Loop Diagram}

Diagram Kausatik adalah suatu diagram ytang berisikan sebab akibat yang menjadi alat untuk merepresentasikan struktur timbal balik dari sistem yang dimodelkan[14]. Diagram kausatik terdiri atas variabel yang saling berhubungan dengan panah (link) dengan prioritas ( + dan - ) serta penundaan ( $\|$ ). Tanda tersebut menunjukan apakah timbal balik yang dilakukan adalah positif ataupun negatif.

\section{F. Purwarupa Aplikasi}

Suatu metode yang dapat dilakukan dengan membuat gambaran singkat terkait dengan aplikasi ataupun sistemyang akan diterpakan, metode purwarupa ini dilakukan apabila client belum dapat menyebutkan spesifikasi kebutuhan secara lengkap ataupun memang belum dapat memberikan gambaran yang jelas terkait denga pembangunan suatu perangkat lunak. Keunggulan dari metode ini adalah dengan waktu yang singkat, ilustrasi awal aplikasi sebelum dilanjutkan ke pembangunan[15].

\section{METODOLOGI}

\section{A. Studi Literatur}

Pada tahap ini dilakukan pencarian dan pemahaman teoriteori yang mendukung penelitian maupun informasi lain yang menunjang penelitian mengenai pemodelan kontinyu, konsep 
smart mobility, serta identifikasi masalah terkait dengan implementasi sistem smart mobility di Surabaya.

\section{B. Analisis Faktor}

Tahap selanjutnya adalah analisis faktor-faktor yang memengaruhi pengembangan smart mobility. Yang selanjutnya akan di identifikasi beberapa faktor tersebut disesuaikan dengan indikator dari smart mobility yang memengaruhi pembuatan pemodelan dan simulasi. Faktorfaktor tersebut nantinya akan membantu dalam pembuatan causal loop diagram dan stock flow diagram.

\section{Pengumpulan Data}

Setelah dilakukannya analisis terhdapa faktor yang memengaruhi pengembangan smart mobility, tahap selanjutnya adalah menambil data pada sumber yaitu dishub Surabaya, dengan adanya dukungan data dari narasumber yang terkait tersebut, dapat membantu dalam pembuatan skenario.

\section{Pembuatan Causal Loop Diagram}

Pembuatan causal loop diagram dilakukan sebelum disimulasikan kedalam stock flow diagram. Tujuan digunakannya diagram kausatik adalah untuk membantu dalam mengklasifikasikan faktor-faktor serta indikator smart mobility ke dalam diagram kausatik.

\section{E. Pembuatan Stock Flow Diagram}

Dalam pembuatan stock flow diagram, variabel-variabel yang diambil berasal dari causal loop diagram. Kemudian di klasifikasikan variabel mana saja yang masuk ke level, parameter dan initial condition-nya.

\section{F. Verifikasi dan Validasi}

Tahap selanjutnya adalah melakukan verifikasi untuk memastikan apakah program komputer dan implementasi konseptual tidak terjadi galat setalah dimasukannya formulas i model pada variabel di stock flow diagram. Setelah dilakukannya verifikasi, dilakukan validasi untuk memastikan luaran perilaku model sudah akurat dan sesuai dengan ekspektasi dan kenyataan dilapangan. Dengan cara behavior pattern test yaitu membandingkan hasil rata-rata $\mathrm{dn}$ variasi amplitude.

\section{G. Pembuatan Skenario}

Pada tahap ini akan dilakukan perilaku sistem berdasarkan spesifikasi skenaro yang dapat terjadi. Penggunaan skenario ini bertujuan untuk seberapa rigid sistem yang dibuat dan bagaimana apabila adanya skenario tertentu, dapat membuat efek yang baik jika ditambahkan skenario yang ada.

\section{H. Analisa hasil dan Pembuatan Purwarupa}

Selanjutnya adalah dilakukan analis is yang akan mendapatkan struktur model yang baru. Dari beberapa skenario yang dilakukan, di pilih salah satu skenario dengan luaran yang terbaik, Skenario ini yang selanjutnya akan menjadi model pendukung keputusan implementasi dari smart mobility di Surabaya, Setelah analisa hasil, dibuat purwarupa aplikasi dengan Google Maps API.

\section{MODEL DAN IMPELEMNTASI}

\section{A. Pengolahan Data}

Pada tahap ini dilakukan proses pengolahan data yang didapatkan berdasarkan dari data publikasi LHR Surabaya,
Laka Lantas dan Data sensus penduduk untuk dilakukannya analis is faktor dari data yang dibutuhkan. Proses pengolahan data berujjuan untuk merumuskan hubungan antar masingmasing variabel yang akan memengaruhi perkembangan smart mobility Kota Surabaya. Beberapa tahapan dalam mengembangkan model dalam penelitian ini antara lain sebagaiberikut :

- Model Diagram Kausatik

- Model Diagram Flow

- Verifikasi Model

- Validasi Model

- Rancangan Skenario

\section{B. Model Diagram Kausatik}

Langkah selanjutnya adalah pembuatan simulasi sistem dinamik adalah dengan merumuskan model sesuai dengan kondisi terkini (esisting) lalu lintas Kota Surabaya. Hal yang paling utama dalam pembuatan konsep diagram kausatik adalah identifikasi dari diagram kausatik yang akan dibuat, berdasarkan dari analsa faktor yang telah dilakuakn, berikut adalah model diagram kausatik penelitian ini. (Gambar 1)

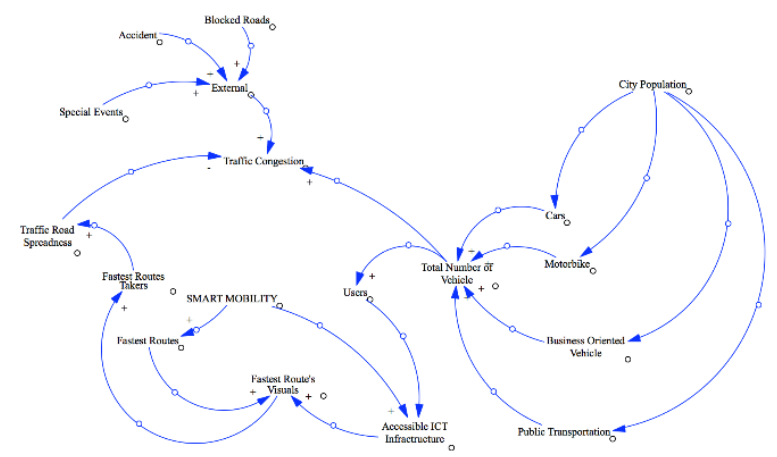

Gambar 1. Model kausatik.

\section{Pemodelan Sistem}

Setelah Didapatkan hubungan antar variabel, selanjutnya dilakukan pembuatan model dengan menggunakan aplikasi Vensim berdasarkan data-data yang telah dikumpulkan sebelumnya. Model tersebut nantinya akan disesuaikan dengan rumusan yang diperoleh dari pengolahan data yang dihasilkan dari formulasi. Gambar 2 merupakan gambar flow diagram :

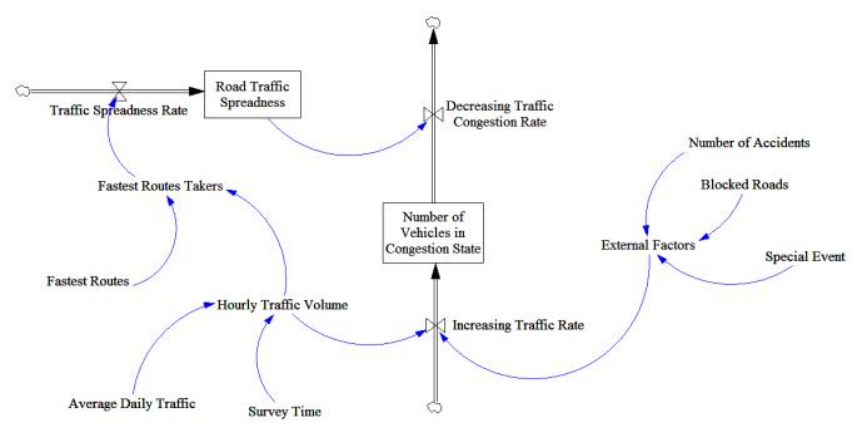

Gambar 2. Flow diagram.

\section{Verifikasi dan Validasi Model}

Verifikasi model bertujuan untuk memastikan bahwa program pada komputer dari model konseptual yang merepresentasikan model sebenarnya tidak terjadi bug. Validasi model bertujuan untuk memastikan apakah luaran perilaku dari model sudah akurat dan sesuai dengan ekspektasi. Pengujian validasi dilakukan dengan uji 
Tabel 1. Validasi ruas A. Yani

\begin{tabular}{|c|c|c|}
\hline "Tahun & $\begin{array}{c}\text { Data Sebenarnya } \\
\text { Kendaraan yang } \\
\text { terkenamacet A. Yani } \\
11147\end{array}$ & $\begin{array}{c}\text { Simulasi banyak } \\
\text { Kendaraan yang terkena } \\
\text { macet A.Yani } \\
10948\end{array}$ \\
\hline 2001 & 21479 & 20563 \\
\hline 2002 & 32750 & 31670 \\
\hline 2003 & 45547 & 43642 \\
\hline 2004 & 57451 & 55198 \\
\hline 2005 & 68743 & 66965 \\
\hline 2006 & 80145 & 79457 \\
\hline 2007 & 89475 & 87968 \\
\hline 2008 & 101486 & 100861 \\
\hline 2009 & 114587 & 111909 \\
\hline 2010 & 124875 & 122411 \\
\hline 2011 & 138752 & 131436 \\
\hline 2012 & 144589 & 140077 \\
\hline 2013 & 160213 & 152255 \\
\hline 2014 & 174896 & 163891 \\
\hline 2015 & 179021 & 172962 \\
\hline 2016 & 185472 & 180791 \\
\hline 2017 & 190546 & 187706 \\
\hline Rata-Rata & 106732 & 103373 \\
\hline $\begin{array}{c}\text { Standar } \\
\text { Dev. }\end{array}$ & 57412.64151 & 55347.93719 \\
\hline
\end{tabular}

perbandingan mean comparison dan $\%$ error variance. Dikatakan valid apabaila nilai mean comparis on $5 \%$ dan nilai $\%$ error variance $30 \%$.

1. Validasi Ruas A. Yani

Tabel 1 adalah validasi dari ruas A. Yani:

Berdasarkan nilai mean comparis on dan standard deviation dari Rata-rata simulasi dengan data asli yaitu adalah E1, memberikan nilai $3.15 \%(<5 \%)$ dan E2 yang menggunakan standardeviasi simulasi dan data asli sebesar $3.60 \%(<30 \%)$. Dari kedua hasil tersebut, dapat dipastikan bahwa model ini valid.

2. Validasi Ruas Raya Rungkut

Tabel 2 adalah validasi dari ruas Raya Rungkut:

Berdasarkan nilai mean comparis on dan standard deviation dari Rata-rata simulasi dengan data asli yaitu adalah E1, memberikan nilai $3.45 \%(<5 \%)$ dan E2 yang menggunakan standar deviasi simulasi dan data as li sebesar $3.30 \%(<30 \%)$. Dari kedua hasil tersebut, dapat dipastikan bahwa model ini valid.

\section{SKENARIO DAN ANALISA HASIL}

\section{A. Pengembangan Skenario}

Skenario dikembangkan ketika basemodel telah melalui tahapan verifikasi dan validasi. Peningkatan pengurangan tingkat kepadatan jalan, berikut adalah Skenario yang digunakan pada penelitian ini untuk memaksimalakan penurunan tingkat kepada tan jalan, berikut adalah skenario yang digunakan :

1. Skenario Penambahana Jalur Alternatif
Tabel 2.

Validasi dari ruas Raya Rungkut

\begin{tabular}{|c|c|c|}
\hline$\overline{\text { Tahun }}$ & $\begin{array}{c}\text { Data Sebenarnya } \\
\text { Kendaraan yang terkena } \\
\text { macet Raya Rungkut } \\
6254\end{array}$ & $\begin{array}{c}\text { Simulasi banyak } \\
\text { Kendaraan yang terkena } \\
\text { macet Raya Rungkut } \\
6190\end{array}$ \\
\hline 2001 & 12335 & 12270 \\
\hline 2002 & 19547 & 18443 \\
\hline 2003 & 26879 & 24699 \\
\hline 2004 & 32547 & 30792 \\
\hline 2005 & 38475 & 36725 \\
\hline 2006 & 45178 & 42954 \\
\hline 2007 & 49652 & 48200 \\
\hline 2008 & 57412 & 54225 \\
\hline 2009 & 60248 & 59803 \\
\hline 2010 & 66524 & 65191 \\
\hline 2011 & 70145 & 69672 \\
\hline 2012 & 77558 & 74338 \\
\hline 2013 & 79842 & 78687 \\
\hline 2014 & 85476 & 83739 \\
\hline 2015 & 90145 & 88643 \\
\hline 2016 & 97584 & 93550 \\
\hline 2017 & 105489 & 97967 \\
\hline Rata-Rata & 56738 & 54783 \\
\hline Standar Dev. & 29002.00062 & 28028.95875 \\
\hline
\end{tabular}

Skenario yang dilakukan pertama adalah penambahan jalu r disetiap ruas, yaitu dengan menambahkan 1 jalur alternatif yang dapat digunakan oleh pengguna jalan. Pada skenario ini digunakan nilai konfidensi sebesar $1.25 \%$ untuk pengguna jalan alternatif dikarenakan adanya penambahan jalur untuk dapat digunakan.

2. Skenario Pemgadaan ICT Penyaranan Tempat

Skenario selanjutnya adalah dengan adanya implementas i dari teknologi ICT yang membuat pengguna dapat mengakses tempat umum alternatif seperti pust perbelanjaan, tempat rekreasi atau lainnya apabila terjadi kepadata dijalan menuju tempat pilihan awal dari pengguna, dengan begitu, kepadatan jalan dapat terurai.

\section{B. Hasil Analisis Skenario}

Perbandingan skenario pada Ruas A. Yani dapat dilihat pada Gambar 3.

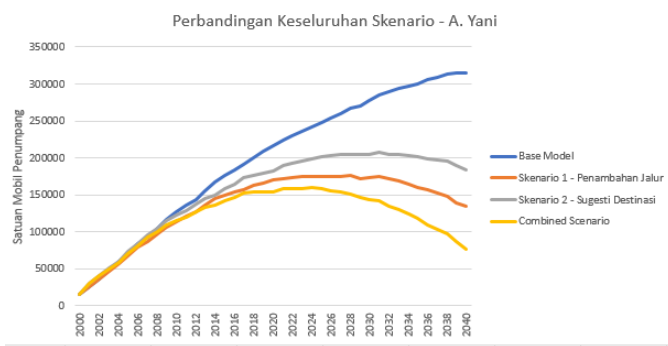

Gambar 3. Perbandingan skenario pada Ruas A. Yani.

Dari hasil simulasi diatas, dapat terlihat bahwa untuk Ruas A. Yani, efektivitas yang sangat baik dadalah apabila memadukan kedua skenario, namun apabila harus memeilih 
salah satu skenario yang ada, yang paling efektif adalah skenario penambahan jalur alternatif. Dengan nilai rataaan dari jumlah kendaraan dari tahun 2000 hingga 2040 sebesar 165510.

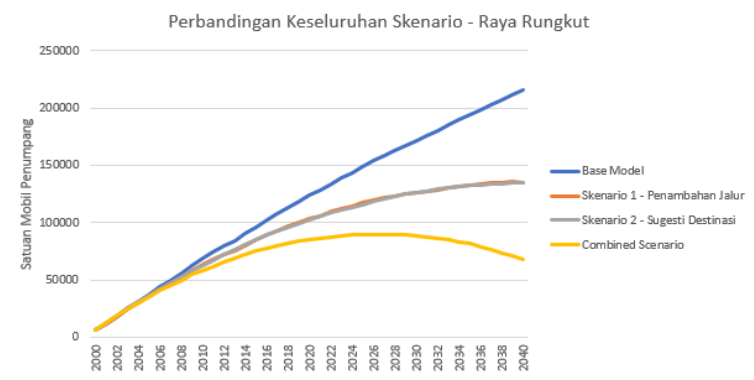

Gambar 4. Perbandingan Skenario pada Rusa Raya Rnngkut.

Untuk skenario pada Ruas Raya Rungkut, dapat dilihat pada Gambar 4, kedua skenario saling berdekatan secara grafik, namun yang palingbaik adalah dengan membuat sistem ICT Penyaranan tempat alternatif, dengan rataan 121234.

Jadi, dapat disimpulkan, untuk ruas A. Yani skenario yang dapat diterapkan adalah penambahan jalur alternatif, dan untuk Raya Rungkut adalah Penyaranan ICT Tempat umum, namun tidak serta merta dapat langsung menggunakan keputusan tersebut, pemerintah kota dapat menerapkan sesuai dengan kebutuhan ataupun risiko yang ada terkait dengan penerapan skenario tersebut

Tahap terakhir adalah visualisasi dari sistem menggunakan API Google Maps pada android, dipilihnya android, dikarenakan pengguna android jauh lebih banyak dari pada platform lain. Tools yang digunakan pada tahap visualisasi ini adalah Android Studio dan perangkat android untukADB Demo, berikut adalah gambar hasil dari visualiasi

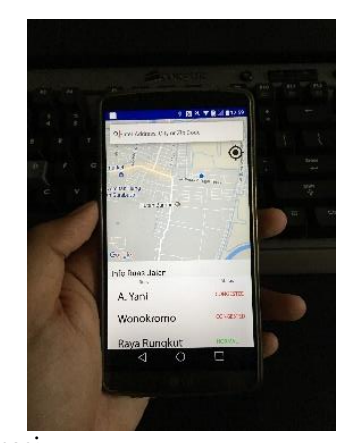

Gambar 5. Hasil visualisasi

\section{KESIMPULAN/RINGKASAN}

Kesimpulan yang didapatkan berdasarkan hasil penelitian ini adalah :

1. Indikator penurunan kepadatan jalan dapat dilakukan dengan hanya memanipulasi nilai konfidensi yang ada pada sistem. .
2. Model yang digunakan pada penelitian ini telah valid dan sesuai dengan sistem nyata, dengan membuktikan $\mathrm{E} 1<5 \%$ dan $\mathrm{E} 2<30 \%$

3. Seknario yang dibuat adalah berdasarkan dari implementasi Transportation Management System yang meminimalis ir demand atau penggunaan jalan dengan supply atau ketersdiaan dari jalan. Untuk implementasi yang tepat pada A. Yani, direkomendasikan menggunakan skenario penambahan jalur alternative, sedangkan Raya Rungkut, yaitu implementasi ICT Penyaranan Tempat Umum.

4. Penggunaan visualisasi on-demand seperti android lebih intuitif dibandingkan dengan penggunaan desktop yang cukup menyulitkan apabila harus membawa perangkat.

\section{DAFTAR PUSTAKA}

[1] K. Boriboonsomsin, M.J. Barth, W. Zhu, and A. Vu, "Eco-routing navigation system based on multisource historical and real-time traffic information," IEEETrans. Intell. Transp. Syst., vol. 13, no. 4, pp. 1694-1704, 2012.

[2] D. Levinson, "The value of advanced traveler information systems for route choice."

[3] R. L. Eberlein and D. W. Peterson, "Understanding models with Vensim ${ }^{\text {TM }, " ~ E u r . ~ J . ~ O p e r . ~ R e s ., ~ v o l . ~ 59, ~ n o . ~ 1, ~ p p . ~ 216-219, ~ M a y ~}$ 1992.

[4] V. Albino, U. Berardi, and R. M. Dangelico, "Smart Cities: Definitions, Dimensions, Performance, and Initiatives," J. Urban Technol., vol. 22, no. 1, pp.3-21, Jan. 2015.

[5] R. Giffinger, "Smart cities Ranking of European medium-sized cities," October, vol. 16, no. October, pp. 13-18, 2007.

[6] V. Chichernea, "THE USE OF DECISION SUPPORT SYSTEMS (DSS) IN SMART CITY PLANNING AND MANAGEMENT Virgil Chichernea 1," J. Inf. Syst. Oper. Manag.,pp. 1-14, 2014.

[7] R. Giffinger, "Smart cities Ranking of European medium-sized cities," October, vol. 16, no. October, pp. 13-18, 2007.

[8] C. Benevolo, R. P. Dameri, and B. D'Auria, "Smart mobility in smart city action taxonomy, ICT intensity and public benefits," in Lecture Notes in Information Systems and Organisation, vol. 11, 2016, pp. 13-28.

[9] M. Quddus A, C. Wang, S. Ison G, M. A. Quddus, C. Wang, and S. G. Ison, "Road Traffic Congestion and Crash Severity: Econometric Analysis Using Ordered Response Models," $J$. Transp. Eng., vol. 136, no. 5, p. pp 424-435, 2010.

[10] D. A. Hennessy and D. L. Wiesenthal, "Traffic congestion, driver stress, and driver aggression," Aggress. Behav., vol. 25, no. 6, pp. 409-423, 1999.

[11] R. Bauza, J. Gozalvez, and J. Sanchez-Soriano, "Road Traffic Congestion Detection through Cooperative Vehicle-to-Vehicle Communications."

[12] A. Downs, Still Stuck in Traffic. 2004.

[13] R. G. Coyle, System Dynamic Modelling. 1996.

[14] J. D. Sterman, "Business Dynamics. System Thinking and Modeling for A Complex World," McGraw-Hill Educ. Bost., no. January 2000, p. 982 pp, 2000.

[15] M. Tuteja and G. Dubey, "A Research Study on importance of Testing and Quality Assurance in Software Development Life Cycle ( SDLC ) Models," Int. J. Soft Comput. Eng., vol. 2, no. 3, pp. 251-257, 2012. 